\title{
Modulatory Role of Selenium and Vitamin E, Natural Antioxidants, against Bisphenol A-Induced Oxidative Stress in Wistar Albinos Rats
}

\author{
Wahiba Amraoui ${ }^{1,2}$, Nesrine Adjabi ${ }^{2}$, Fatiha Bououza ${ }^{2}$, Mahieddine Boumendjel ${ }^{1}$, Faiza Taibi ${ }^{1}$, \\ Amel Boumendjel ${ }^{1}$, Cherif Abdennour ${ }^{2}$ and Mahfoud Messarah ${ }^{1}$ \\ 'Laboratory of Biochemistry and Environmental Toxicology, Faculty of Sciences, Badji Mokhtar University, Annaba, \\ Algeria \\ ${ }^{2}$ Laboratory of Animal Ecophysiology, Faculty of Sciences, Badji Mokhtar University, Annaba, Algeria
}

\begin{abstract}
Bisphenol A, an everywhere chemical, is applied as a plasticizer in polycarbonate plastics, which often used in our everyday products and in epoxy resins as protective coatings and linings for food and beverage cans for decades. Human exposure to BPA may lead to adverse effects by interfering with oestrogen receptors. Our present study was conducted to investigate the protective effects of selenium ( $\mathrm{Se}$ ) and vitamin E (Vit E) on BPA-induced damage in the liver of male rats. Animals were randomly divided into four groups: the first group received olive oil and served as control. The second group received both ( $\mathrm{Se}+\mathrm{Vit} \mathrm{E})(0.5 \mathrm{mg} / \mathrm{kg}$ diet; $100 \mathrm{mg} / \mathrm{kg}$ of diet). The third one treated orally by $(10 \mathrm{mg} / \mathrm{kg}$ b.w.) of BPA. The last group received ( $\mathrm{Se}+\mathrm{Vit} \mathrm{E})(0.5 \mathrm{mg} / \mathrm{kg} \mathrm{diet;} 100 \mathrm{mg} / \mathrm{kg}$ of diet) concomitantly with $(10 \mathrm{mg} / \mathrm{kg}$ b.w. $)$ BPA. Exposure to BPA for three weeks engendered a hepatic disorder. An increased AST and ALT enzymatic activity was noticed in BPA-treated group as compared to other groups. Furthermore, a change in glucose, cholesterol, LDL-C, HDL-C, albumin, and bilirubin level was remarkable. Moreover, exposure to BPA increased malondialdehyde levels while reduced gluthatione content was decreased in the liver homogenate. A decrease in glutathione peroxidase, glutathione s-transferase and catalase activities was observed in the same group. Administration of selenium and vitamin E through the diet in BPA treated rats ameliorated the biochemical parameters cited above. In addition, an improvement in activities of liver enzymes was recorded. The histological findings confirmed the biochemical results. The model of this study that we employed characterized the relationships between BPA-induced hepatotoxicity and its alleviation by natural antioxidants like selenium and vitamin E.
\end{abstract}

Key words: Bisphenol A, Selenium, Vitamin E, Hepatotoxicity, Oxidative stress, Rat

\section{INTRODUCTION}

Bisphenol A (4, 4'-isopropylidenediphenol) is one of the most ubiquitous synthetic chemical compounds in the

Correspondence to: Mahfoud Messarah, Laboratory of Biochemistry and Environmental Toxicology, Faculty of Sciences, Badji Mokhtar University, BP 12 Sidi Amar, Annaba, Algeria

E-mail: mahfoud.messarah@univ-annaba.dz, mmessarahdz@yahoo.fr

This is an Open-Access article distributed under the terms of the Creative Commons Attribution Non-Commercial License (http:// creativecommons.org/licenses/by-nc/3.0) which permits unrestricted non-commercial use, distribution, and reproduction in any medium, provided the original work is properly cited. plastic production today (1). Previously, it was used as a synthetic oestrogen usually prescribed to prevent miscarriage in pregnant women (2). Nowadays, it is widely used as an antioxidant component in polycarbonate plastics, epoxy resins and as a coating on metal lids for glass jars and bottles, including containers used for infant recipe (3).

It is mostly acknowledged that BPA has harmful effects on both animal and human health $(4,5)$. Given studies regarding BPA have generally focused on the reproductive system. In mammals, BPA binds and activates the two estrogen receptors ER $\alpha$ and ER $\beta$, though with an affinity 10,000 -fold weaker than for their natural ligand $17 \beta$-estradiol (6). It may act via a G-protein-coupled receptor (GPR30), acting as a trans-membrane estradiol receptor (7). Effects via 
other ligand nuclear hormone receptors, such as the thyroid hormone receptor, the androgen receptor, and the glucocorticoid receptors, have also been suggested (8). More recently, the orphan nuclear receptor estrogen-related receptor $\gamma($ ERR $\gamma$ ) has been shown to bind BPA at the nanomolar range $(5.6 \mathrm{nM})$ with high specificity (9). Therefore, bisphenol A impairs male fertility and disrupting bloodtestis barrier $(4,10)$. In addition, it is related to coronary artery disease and may affect thyroid function $(11,12)$, renal disease and exhibits nephrotoxicity (13), oxidative stress leading to mitochondrial dysfunction in liver (14). However, to date, no clear link between an in vivo effect of BPA and one of these different targets has been determined.

The antioxidant defence system of our body depends on large and various protection mechanisms to keep reactive oxygen species (ROS) originating from endogenous or exogenous sources at physiologically optimal levels (15). Natural antioxidants supplementation are largely used to scavenge oxidative impairment induced by these free radicals. Since both Selenium and vitamin E possess biological and antioxidant properties, they are recently used to constrain oxidative damages (16-19). Selenium is a micronutrient required in selenoproteins such as glutathione peroxidase (GPx) which ultimately allows the enzymes to be even more reactive $(17,18)$. On the other hand, vitamin $E$ is a fat-soluble antioxidant essential for the majority of metabolic processes preventing lipid peroxidation. It has a crucial role in anti-inflammatory processes, inhibition of platelet aggregation, and immune enhancement $(19,20)$. Subsequently, vitamin E ( $\alpha$-tocopherol) is a chain-breaking antioxidant to inhibit the propagation step where the alkyl radical reacts with molecular oxygen at a very high rate, giving a peroxyl radical. $\alpha$-tocopherol efficiently transfers a hydrogen atom to a lipid free radical; $\alpha$-tocopheroxyl radicals and stops the chain reaction $(21,22)$. Earlier studies had shown that dietary selenium and vitamin $\mathrm{E}$ intake reinforces the level of glutathione peroxidase $(23,24)$. In addition, previous studies were occurred on the protective effects of selenium alone or vitamin $\mathrm{E}$ alone on BPAtreated animals. The results showed that selenium or vitamin $\mathrm{E}$ ameliorated the toxicity induced by BPA in liver, testis and lungs (25-27). Growing investigations had shown that both selenium and vitamin $\mathrm{E}$ are more powerful to scavenge ROS synergistically $(16,28,29)$.

Further, the liver exhibits one of the highest antioxidant enzyme capacity in the body. It is involved in many biological processes including glycogen storage, decomposition of red blood cells, plasma protein synthesis, detoxification and others (30). According to data, this tissue is one of the main targets of the bisphenol A and its metabolites $(3,14,31)$. Thus, the present study was conducted to evaluate lipid peroxidation and oxidative stress induced by BPA in liver rat, and the possible protective effect of selenium and vitamin E supplementation, since it has not yet been investigated.

\section{MATERIALS AND METHODS}

Reagents. BPA $\left(\mathrm{C}_{15} \mathrm{H}_{16} \mathrm{O}_{2}, \mathrm{CAS} \#\right.$ 80-05-7, Sigma Aldrich, MO, USA) is a synthetic oestrogen used as a polymer in the plastics output. IUPAC name: 4, 4'-(propan-2ylidene) diphenol (Fig. 1). Sodium selenite $\left(\mathrm{Na}_{2} \mathrm{SeO}_{3}\right.$, CAS \# 10102-18-8, Sigma Aldrich). $\alpha$-Tocophérol $\left(\mathrm{C}_{29} \mathrm{H}_{50} \mathrm{O}_{2}\right.$, CAS \# 59-02-9, Vetoquinol Italia, Italy). All other chemical products used in this study were purchased from Sigma Aldrich.

Experimental design. Twenty-eight male rats of Wistar strain weighing $(250 \sim 270 \mathrm{~g})$ were obtained from the Algerian Pasteur Institute (Algiers, Algeria). Food (standard diet, supplied by the ONAB/Food Unit of El-Kseur, Bejaia, Algeria) and water were available ad libitum. Animals were acclimated for two weeks under conventional conditions. The experiment took place for three weeks successively, where rodents were randomly assigned into four groups of seven individuals each as follow:

- Groups 1 was orally received olive oil and serving as control

- Groups 2 was received selenium $(0.5 \mathrm{mg} / \mathrm{kg}$ of diet $)$ and vitamin E (100 mg/kg of diet.)

- Groups 3 treated orally by $10 \mathrm{mg} / \mathrm{kg}$.b.w. of bisphenol A

- Groups 4 was concomitantly administered (Se + vit E) with BPA

The dose of BPA used in this study represents $1 / 320$ of LD50 (10 mg/kg.b.w) which had been used previously by other investigators since it is toxic but not lethal to rats (32). The dose of selenium $(0.5 \mathrm{mg} / \mathrm{kg}$ of diet $)$ used in our experiment and in other findings gave high protection against stress conditions in several tissues $(17,18)$. The dose of vitamin E $(100 \mathrm{mg} / \mathrm{kg}$ of diet $)$ gave high protection against toxicity in an earlier study (33).

During treatment, body weight and food intake were recorded periodically during the experiment weeks. After an overnight fast, animals were sacrificed by decapitation and blood samples were immediately collected into tubes without anticoagulant and centrifuged at 5,000 rpm for $5 \mathrm{~min}$. The separated serum was allocated into aliquots for biochemical assays. Later, their livers were carefully removed, weighed and were placed either in a buffer solu-<smiles>CC(C)(c1ccc(O)cc1)c1ccc(O)cc1</smiles>

Fig. 1. Chemical structure of bisphenol $A$. 
tion of TBS (Tampon buffered saline, $50 \mathrm{mM}$ Tris, 150 $\mathrm{mM} \mathrm{NaCl}, \mathrm{pH} 7.4$ ) at a temperature of $4^{\circ} \mathrm{C}$ for oxidative damage analysis, or in formol solution $(10 \%)$ for histopathological studies. One gram of liver was homogenised in $2 \mathrm{~mL}$ of TBS by an ultrasound homogeniser. Homogenates were centrifuged at $9,000 \mathrm{rpm}$ for $15 \mathrm{~min}$ at $4^{\circ} \mathrm{C}$, and the supernatants were divided into aliquots and stored at$20^{\circ} \mathrm{C}$ before being used. All experiments were fulfilled in accordance with European Commission guidelines for the accommodation and care of animals used for experimental and other scientific purposes (33).

Biochemical assays. The transaminase activities; aspartate transaminase: AST and alanine transaminase: ALT, albumin as well as total bilirubin, direct bilirubin, glucose, cholesterol, LDL-C (Low Density Lipoprotein Cholesterol), HDL-C (Height Density Lipoprotein Cholesterol) and triglycerides were measured using commercial kits obtained from Spinreact (Barcelona, Spain).

\section{Lipid peroxidation levels and antioxidant status.}

- Estimation of lipid peroxidation: Malondialdehyde (MDA), which is the final product of polyunsaturated fatty acids oxidation, was assessed as a marker for lipid peroxidation and reacts with thiobarbituric acid (TBA) to produce a red coloured complex, which has peak absorbance at $532 \mathrm{~nm}$. Thus, $125 \mu \mathrm{L}$ of supernatant were homogenized by sonication with $50 \mu \mathrm{L}$ of PBS, $125 \mu \mathrm{L}$ of TCABHT (trichloroacetic acid-butylhydroxytoluene) in order to precipitate proteins, and then centrifuged $(1,000 \mathrm{rpm}$ for $10 \mathrm{~min}$, at $4^{\circ} \mathrm{C}$ ). Afterwards, $200 \mu \mathrm{L}$ of supernatant were mixed with $40 \mu \mathrm{L}$ of $\mathrm{HCl}(0.6 \mathrm{M})$ and $160 \mu \mathrm{L}$ of TBA dissolved in Tris, and then the mixture was heated at $80^{\circ} \mathrm{C}$ for $10 \mathrm{~min}$. The absorbance of the resultant supernatant was obtained at $530 \mathrm{~nm}$. The amount of TBARS was calculated using a molar extinction coefficient of $1.56 \times 10^{5} \mathrm{M} /$ $\mathrm{cm}$ (34).

- Reduced glutathione level: Analysis of GSH level was based on the development of a yellow colour when DTNB is added to components having sulfhydryl groups (35). In brief, $200 \mu \mathrm{L}$ of $0.25 \%$ sulphosalicylic acid was added to $800 \mu \mathrm{L}$ of organ supernatant and tubes were centrifuged at $1,000 \mathrm{rpm}$ for $15 \mathrm{~min}$. Supernatant $500 \mu \mathrm{L}$ was mixed with $1,000 \mu \mathrm{L}$ phosphate buffer $(0.1 \mathrm{M}, \mathrm{pH} 7.4)$ and $25 \mu \mathrm{L}$ of DTNB (10 mM). Finally, absorbance at 412 $\mathrm{nm}$ was recorded. Total GSH content was expressed as (nmol GSH/mg protein).

- Assays of glutathione-S-transferase: The measurement of the activity of GST is based on the conjugation reaction of glutathione and 1-chloro, 2.4-dinitrobenzene (C-DNB) which results a new molecule that absorbs light at $340 \mathrm{~nm}$ (36).

- Assay of glutathione peroxidase activity: The Supernatant obtained after centrifuging $5 \%$ of the liver at 10,000 rpm for $30 \mathrm{~min}$ at $4^{\circ} \mathrm{C}$ was used for GPx assay. Reaction mixture of $1,000 \mu \mathrm{L}$ was prepared which contained $300 \mu \mathrm{L}$ of phosphate buffer ( $0.1 \mathrm{M}, \mathrm{pH} 7.4), 200 \mu \mathrm{L}$ of GSH (2 $\mathrm{mM}), 100 \mu \mathrm{L}$ of sodium azide $(10 \mathrm{mM}), 100 \mu \mathrm{L}$ of hydrogen peroxide $\left(\mathrm{H}_{2} \mathrm{O}_{2}\right)(1 \mathrm{mM})$ and $300 \mu \mathrm{L}$ of tissue supernatant. After incubation at $37^{\circ}$ for $15 \mathrm{~min}$, the reaction was terminated by the addition of $500 \mu \mathrm{L}$ of TCA $(5 \%)$. Tubes were centrifuged at $1,500 \mathrm{~g}$ for $5 \mathrm{~min}$ and the supernatant was collected. Totally, $200 \mu \mathrm{L}$ of phosphate buffer $(0.1 \mathrm{M}$, $\mathrm{pH} 7.4)$ and $700 \mu \mathrm{L}$ of DTNB $(0.4 \mathrm{mg} / \mathrm{mL})$ were added to $100 \mu \mathrm{L}$ of reaction supernatant. After mixing, absorbance was recorded at $420 \mathrm{~nm}$ (37).

- Assay of catalase activity: The reaction was started by adding $20 \mu \mathrm{L}$ of $\mathrm{H}_{2} \mathrm{O}_{2}(0.5 \mathrm{M})$ to $200 \mu \mathrm{L}$ of supernatant and $780 \mu \mathrm{L}$ of phosphate buffer $(0.1 \mathrm{M}, \mathrm{pH} 7.4)$. Later, the decomposition was monitored by following the decrease in absorbance at $240 \mathrm{~nm}$ for $1 \mathrm{~min}$. The enzyme activity was calculated by using an extinction coefficient of $0.043 \mathrm{mM}^{-1} \mathrm{~cm}^{-1}$ (38).

- Protein assay: The protein content of supernatant was spectro-photometrically estimated using bovine serum albumin as standard (39).

- Histopathological examination: The liver was dissected and was weighed in order to calculate organ/body weight ratio for each animal. After weighing, tissue samples were fixed in $10 \%$ formol and proceed to routine histopathological process. Then, they were dehydrated in 70 $100 \%$ ethanol series and were embedded in the paraffin baths at $58^{\circ} \mathrm{C}$ for paraffin inclusion. Sections of $4 \sim 6 \mu \mathrm{M}$ were prepared from paraffin blocks using a Leica Rotary Microtomy (Wetzlar, Germany). These sections were then stained with Hematoxylin-Eosin (H-E) according to standards. All slides were evaluated and photographed under a light microscope (Leica DM 500, Leica light microscope, Wetzlar, Germany).

- Statistical analysis: All the results were expressed as Mean value \pm SEM. Data comparisons were carried out by using one way analysis of variance followed by post hoc of tukey test to compare means between the different treated groups. Differences were considered statistically significant at $p \leq 0.05$.

\section{RESULTS}

Effect of BPA on both body and liver weight. Body weight of treated rodents with bisphenol A was increased significantly compared to untreated animals $(13 \%$ to $8.16 \%$ ). After the first week of treatment, rodents progressively gained weight until $331 \mathrm{~g}$ at the end of the experiment. Whereas, the body weight was maintained normally in the mixture group [BPA + $(\mathrm{Se}+\mathrm{Vit} \mathrm{E})]$ even lower than the control and ( $\mathrm{Se}+\mathrm{Vit} \mathrm{E})$ groups (Table 1). However, absolute and relative weight of liver did not reveal any change between different groups. 
Table 1. Effects of treatments on body weight $(\mathrm{g})$, absolute $(\mathrm{g})$ and relative liver weights $(\mathrm{g} / 100 \mathrm{~g} \mathrm{bw})$, daily food intake (g) in experimental groups

\begin{tabular}{|c|c|c|c|c|}
\hline Parameters & Control & $(\mathrm{Se}+\mathrm{Vit} \mathrm{E})$ & BPA & $\mathrm{BPA} /(\mathrm{Se}+\mathrm{Vit} \mathrm{E})$ \\
\hline Initial body weight $(\mathrm{g})$ & $275.66 \pm 4.2^{\mathrm{a}}$ & $271.83 \pm 2.91^{\mathrm{a}}$ & $270.25 \pm 2.51^{\mathrm{a}}$ & $270.5 \pm 2.31^{\mathrm{a}}$ \\
\hline Final body weight $(\mathrm{g})$ & $300 \pm 5.94^{b}$ & $310.62 \pm 6.91^{\mathrm{b}}$ & $345.5 \pm 9.4^{\mathrm{a}}$ & $291.75 \pm 5.3^{b}$ \\
\hline Body gain weight $(\%)$ & $8.16 \pm 2.35^{\mathrm{b}}$ & $8.87 \pm 1.51^{\mathrm{b}}$ & $19 \pm 2.03^{\mathrm{a}}$ & $3.8+2.13^{\mathrm{b}}$ \\
\hline Absolute liver weight (g) & $8.12 \pm 0.58^{\mathrm{a}}$ & $7.92 \pm 0.36^{\mathrm{a}}$ & $8.374 \pm 0.35^{\mathrm{a}}$ & $8.28 \pm 0.3^{\mathrm{a}}$ \\
\hline Relative liver weight(g/100 g bw) & $2.6 \pm 0.1^{\mathrm{a}}$ & $2.7 \pm 0.11^{\mathrm{a}}$ & $2.934 \pm 0.1^{\mathrm{a}}$ & $2.63 \pm 0.05^{\mathrm{a}}$ \\
\hline Food intake (g/day/rat) & $19.75 \pm 0.77^{\mathrm{a}}$ & $21.7 \pm 0.9^{\mathrm{a}}$ & $17.62 \pm 1^{\mathrm{b}}$ & $17.09 \pm 2.7^{\mathrm{b}}$ \\
\hline
\end{tabular}

Values are given as mean \pm SEM for groups of 7 animals each.

${ }^{a-c}$ Means in a row without a common superscript letter differ $(p<0.05)$ as analyzed by two-way ANOVA and the TUKEY test.

Table 2. Effects of treatments on plasma biochemical parameters of control and treated rats

\begin{tabular}{lcccc}
\hline \hline Parameters & \multicolumn{1}{c}{ Control } & (Se + Vit E) & \multicolumn{1}{c}{ BPA } & BPA/(Se +Vit E) \\
\hline Glucose (g/L) & $1.31 \pm 0.05^{\mathrm{b}}$ & $1.54 \pm 0.07^{\mathrm{b}, \mathrm{a}}$ & $1.65 \pm 0.08^{\mathrm{a}}$ & $1.53 \pm 0.08^{\mathrm{b}, \mathrm{a}}$ \\
Cholesterol (g/L) & $0.98 \pm 0.07^{\mathrm{b}}$ & $0.89 \pm 0.01^{\mathrm{b}}$ & $1.32 \pm 0.08^{\mathrm{a}}$ & $1.02 \pm 0.04^{\mathrm{b}}$ \\
LDL-C (g/L) & $0.13 \pm 0.01^{\mathrm{b}}$ & $0.18 \pm 0.01^{\mathrm{b}}$ & $0.24 \pm 0.03^{\mathrm{a}}$ & $0.17 \pm 0.01^{\mathrm{b}}$ \\
Triglycerides (g/L) & $0.49 \pm 0.01^{\mathrm{b}}$ & $0.44 \pm 0.02^{\mathrm{b}}$ & $0.80 \pm 0.05^{\mathrm{a}}$ & $0.55 \pm 0.02^{\mathrm{b}}$ \\
HDL-C (g/L) & $0.28 \pm 0.02^{\mathrm{a}}$ & $0.26 \pm 0.01^{\mathrm{a}, \mathrm{b}}$ & $0.21 \pm 0.01^{\mathrm{c}}$ & $0.25 \pm 0.01^{\mathrm{a}, \mathrm{b}}$ \\
Albumin (g/L) & $33.74 \pm 1.25^{\mathrm{a}}$ & $30.76 \pm 0.94^{\mathrm{a}}$ & $29.19 \pm 0.72^{\mathrm{b}}$ & $33.69 \pm 0.83^{\mathrm{a}}$ \\
Total bilirubin (mg/dL) & $2.11 \pm 0.02^{\mathrm{c}}$ & $2.14 \pm 0.04^{\mathrm{c}}$ & $2.49 \pm 0.03^{\mathrm{a}}$ & $2.27 \pm 0.117^{\mathrm{b}}$ \\
Direct bilirubin (mg/dL) & $0.14 \pm 0.01^{\mathrm{a}}$ & $0.14 \pm 0.01^{\mathrm{a}}$ & $0.15 \pm 0.01^{\mathrm{a}}$ & $0.16 \pm 0.01^{\mathrm{a}}$ \\
ALT (U/L) & $107.71 \pm 3.78^{\mathrm{b}}$ & $124.29 \pm 5.26^{\mathrm{b}}$ & $155.71 \pm 5.15^{\mathrm{a}}$ & $131 \pm 4.14^{\mathrm{a}}$ \\
AST (U/L) & $89.14 \pm 4.38^{\mathrm{c}}$ & $93.29 \pm 5.67^{\mathrm{c}}$ & $132.43 \pm 6.09^{\mathrm{a}}$ & $115 \pm 4.42^{\mathrm{b}}$ \\
\hline
\end{tabular}

Values are given as mean \pm SEM for groups of 7 animals each.

${ }^{\text {a-c }}$ Means in a row without a common superscript letter differ $(p<0.05)$ as analyzed by two-way ANOVA and the TUKEY test.

LDL-C: Low Density Lipoprotein Cholesterol; HDL-C: Height Density Lipoprotein Cholesterol; ALT: Alanine Transaminase; AST: Aspartate Transaminase.

Effect of BPA on the changes of biochemical profile. In Table 2, rats treated for 3 weeks with BPA had a higher concentration of blood sugar compared to the control animals. However, no significant change was found statistically in the mean of the groups: (Se + Vit E) and [BPA/ (Se + Vit E)] compared to control group. Our data showed that chronic exposure to BPA had engendered a hepatic disorder. Where albumin was significantly declined in the BPA-treated group compared to control. Whereas, total bilirubin concentration was significantly increased in the same group with no change in the direct bilirubin as compared to non-treated rodents. Furthermore, the enzymatic activity of AST and ALT had shown a significant increase in the BPA-treated rodents compared to the control ones. Likewise, lipid profile of BPA-treated rats presented a significant increase in total cholesterol, triglycerides and LDL-C levels while the level of HDL-C was decreased.

On the other hand, selenium and vitamin E supplementation significantly improved those dosed parameters above. Indeed, total and direct bilirubin had shown a significant decrease as well as the enzymatic activity of AST and ALT. Likewise, total cholesterol, triglycerides and LDL-C were decreased. However, albumin revealed a recovery compared to the BPA-treated group.

\section{Effect of BPA on lipid peroxidation and glutathione} contents. As shown in Table 3, a significant increase in MDA level, the indicator of lipid peroxidation, after the administration of BPA to rats as compared to control ones. While rats treated concomitantly with BPA and (Se + Vit E) showed a significant decrease in MDA concentration as compared to BPA-treated group. On the other hand, BPAtreated rats showed a significant decline in glutathione content (GSH) as compared to controls. Nonetheless, selenium and vitamin $\mathrm{E}$ co-treatment to BPA significantly enhanced GSH content when compared to BPA-treated group. Yet, this recovery of GSH was still lower than normal level.

\section{Effect of BPA on antioxidants enzymes activities.} Data concerning antioxidant enzymes activity presented in the Table 3, showed a significant decline in the GPx, CAT and GST activities following a treatment with BPA. Yet, a non-significant increase was noticed in the group receiving dietary ( $\mathrm{Se}+\mathrm{Vit} \mathrm{E})$ as compared to control. While rats administered BPA and ( $\mathrm{Se}+\mathrm{Vit} \mathrm{E})$ concomitantly showed a recovery as compared to BPA-treated group yet it is 
Table 3. Effects of BPA on MDA and GSH levels, and liver antioxidant enzymes activities of control and treated rats

\begin{tabular}{|c|c|c|c|c|}
\hline Parameters & Control & $(\mathrm{Se}+\mathrm{Vit} \mathrm{E})$ & BPA & $\mathrm{BPA} /(\mathrm{Se}+\mathrm{Vit} \mathrm{E})$ \\
\hline MDA (nmol/mg prot.) & $0.89 \pm 0.05^{\mathrm{b}}$ & $0.87 \pm 0.05^{\mathrm{b}}$ & $1.248 \pm 0.12^{\mathrm{a}}$ & $0.99 \pm 0.05^{\mathrm{a}, \mathrm{b}}$ \\
\hline GSH (nmol/mg prot.) & $141.1 \pm 14.20^{\mathrm{a}}$ & $130.42 \pm 3^{\mathrm{a}}$ & $93.02 \pm 5^{\mathrm{b}}$ & $124.84 \pm 7.57^{\mathrm{a}}$ \\
\hline GPx (nmoles GSH/min/mg prot.) & $320.2 \pm 11.6^{\mathrm{a}}$ & $290.27 \pm 9^{\mathrm{a}}$ & $192.2 \pm 10.1^{\mathrm{c}}$ & $229.4 \pm 6.38^{\mathrm{b}}$ \\
\hline GST (nmol C-DNB/min/mg prot.) & $15.48 \pm 0.4^{\mathrm{a}}$ & $15.31 \pm 0.27^{\mathrm{a}}$ & $7.37 \pm 0.25^{\mathrm{b}}$ & $11.03 \pm 0.55^{\mathrm{a}}$ \\
\hline CAT ( $\mu$ moles $\mathrm{H}_{2} \mathrm{O}_{2} / \mathrm{min} / \mathrm{mg}$ prot.) & $120.52 \pm 5.61^{\mathrm{a}}$ & $125.6 \pm 4.56^{\mathrm{a}}$ & $95.06 \pm 5.9^{\mathrm{b}}$ & $115.19 \pm 6.24^{\mathrm{b}}$ \\
\hline
\end{tabular}

Values are given as mean \pm SEM for groups of 7 animals each.

${ }^{\text {a-c } M e a n s ~ i n ~ a ~ r o w ~ w i t h o u t ~ a ~ c o m m o n ~ s u p e r s c r i p t ~ l e t t e r ~ d i f f e r ~}(p<0.05)$ as analyzed by two-way ANOVA and the TUKEY test.

Table 4. Semi-quantitative recording of architectural damage on histopathological analysis of the liver of control and treated rats

\begin{tabular}{lcccc}
\hline \hline \multirow{2}{*}{ Parameters } & \multicolumn{5}{c}{ Treatment groups } \\
\cline { 2 - 5 } & Control & $(\mathrm{Se}+\mathrm{Vit}$ E) & BPA & BPA/(Se + Vit E) \\
\hline Degeneration of hepatocytes & - & - & ++ & - \\
Congestions of hepatoportal blood vessels & - & - & ++ & + \\
Inflammatory infiltration & - & + & +++ & + \\
Necrotic foci & - & - & ++ & - \\
\hline
\end{tabular}

$(-)$ indicates normal, $(+)$ indicates mild, (++) indicates moderate, and (+++) indicates severe.

inferior to control groups.

Effect of BPA on hepatic histology. A liver section of control rat was showing a healthy parenchyma, normal hepatic plates radiating from a thin walled central vein (green arrow) separated by blood sinusoids lined by endothelial cells. While, the liver tissue of BPA treated rats shows congestions of hepatoportal blood vessels (blue arrow), inflammatory infiltrations (black arrow) and degeneration of hepatocytes (asterisk) with necrotic foci scattered throughout the liver $(\mathrm{N})$. Liver section of both ( $\mathrm{Se}+\mathrm{Vit} \mathrm{E})$ and the fourth group where rats received both dietary Selenium and vitamin E with BPA showed less inflammatory infiltrations as compared to treated rats with only BPA (Fig. 2). The histopathological changes are graded and summarized in Table 4. Histological grading was made according to four severity grades: - (none); + (mild); ++ (moderate) and +++ (severe).

\section{DISCUSSION}

The present study was carried out to determine the antioxidant capacities of both selenium and vitamin $\mathrm{E}$ to restore the hepatic damage induced by bisphenol $\mathrm{A}$ to male rats. Our results showed a significant increase in the energetic profile parameters such as glucose, cholesterol, LDL-C and triglycerides associated with an overweight following BPA administration compared to non-treated rats. In another hand, relative and absolute liver weight remained unchanged in all dosage groups as compared with the control animals. This is in line with some previous observations in human populations where elevated concentration of urinary BPA was associated with an increased waist circumference as an abdominal obesity factor in Korean adults (5). It seems to down control adipose tissue metabolism, endocrine hormone systems, and the central hypothalamic-pituitary-adrenal axis (40). Specifically, it has been found that low concentrations of BPA induce lipid accumulation mediated by the production of reactive oxygen species in the mitochondria of HepG2 cells (41). However, these findings were not accorded with some studies that have reported a decreased body weight in response to developmental BPA exposures (42), and some others have found no significant effects on body weight, relative or absolute liver weight (43).

As well, activity of enzymes liver function such as aspartate transaminase and alanine transaminase and total bilirubin level was increased comparably to the control rats. Previous studies reported same findings where increased doses of BPA increased the biochemical levels of ALT, AST, ALP and total bilirubin $(44,45)$. However, after being fed with selenium and vitamin E concomitantly with BPA, a recovery of balance was noticed comparing to control rodents. Which endorse the powerful effects of both selenium and vitamin $\mathrm{E}$ to restore the hepatic toxicity of reactive oxygen species generated by several environmental pollutants including BPA $(46,47)$. In fact, there is a growing evidence that nutritional supplements are the essential elements in almost all biological systems and could provide an important dietary source of antioxidants. They latter constrain membrane lipids peroxidation by scavenging lipid peroxyl radicals, and is consequently converted into $\alpha$-tocopheroxyl radical $(16,17)$.

It is acknowledged that hepatic GSH (L-gamma-Glutamyl-L-cysteinyl-glycine) acts as an electrophile, radical scavenger, and a redox partner. GSH may also serve as a 

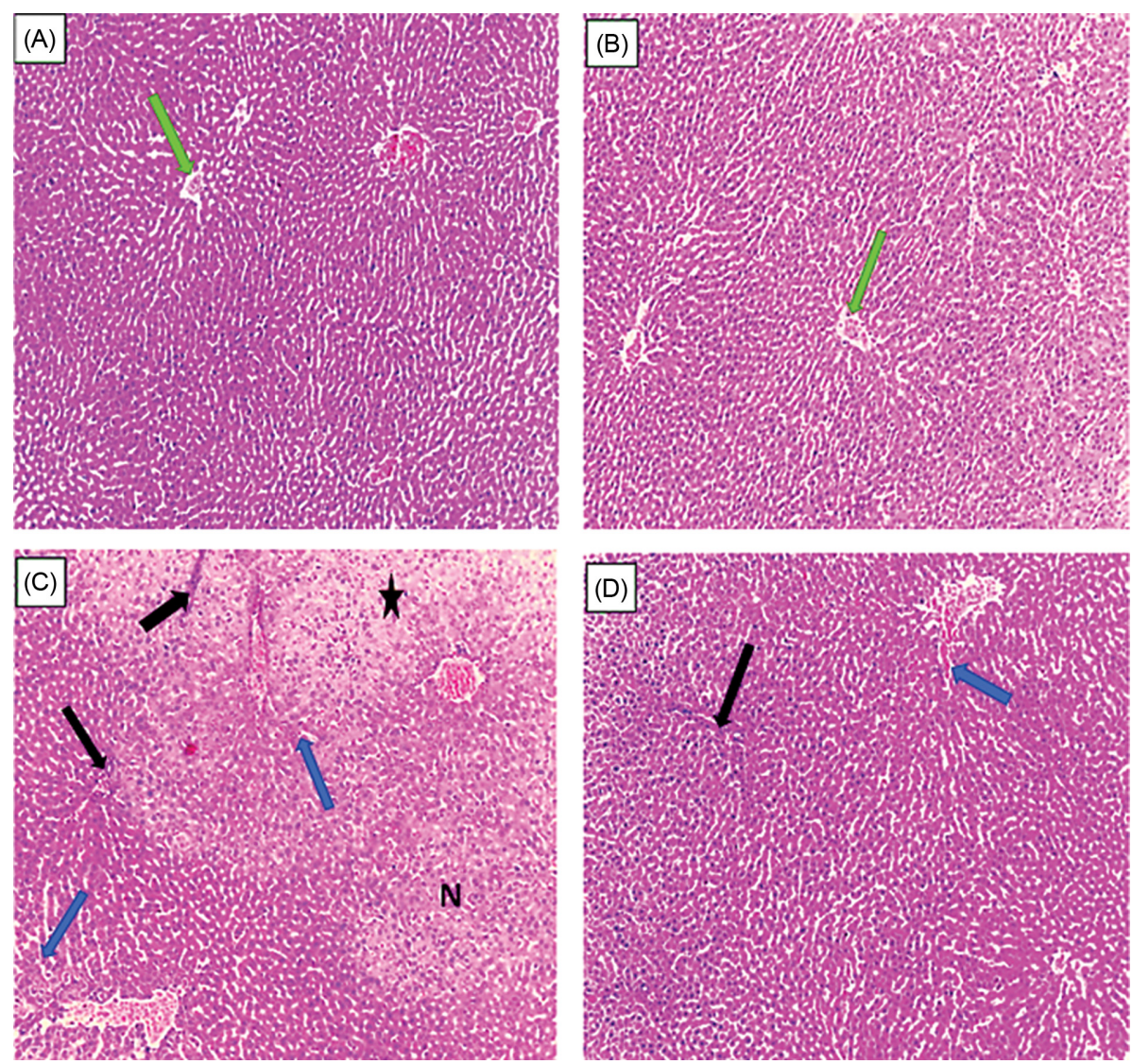

Fig. 2. Histologic sections stained with Hematoxylin-Eosin $(H \& E)$ show the liver of the experimental groups: (A) control rats, (B) $(\mathrm{Se}+\mathrm{Vit}$ E) treated rats, (C) BPA treated rats, (D) (Se + Vit E)/BPA treated rats. (A) Liver section of control rats showing a healthy parenchyma, normal hepatic plates radiating from a thin walled central vein (green arrow) separated by blood sinusoids lined by endothelial cells, polyhedral hepatocytes contained rounded vesicular nuclei $\times 100$. (B) Liver section of (Se + Vit E) treated rats showing a healthy hepatic architecture $\times 100$. (C) The histo-architecture of the liver tissue of BPA treated rats shows congestions of hepatoportal blood vessels (bleu arrows), inflammatory cellular infiltrations (black arrow) and degeneration of hepatocytes (asterisk) with necrotic foci scattered throughout the liver $(\mathrm{N}) \times 100$. (D) The liver section of $(\mathrm{Se}+\mathrm{Vit} \mathrm{E}) / \mathrm{BPA}$ treated rats show few inflammatory cellular infiltrations (black arrow) $\times 100$.

cofactor for several drug-metabolizing enzymes (i.e., GSTs) where it is consumed, or for antioxidant enzymes (i.e., GPx) where it serves as a redox partner (47). During oxidation, GSH forms a dimer, glutathione disulfide (GSSG), which, in turn, can be reduced by the enzyme GR at the expense of NADPH (48). The reduction in activities of antioxidant enzymes in our study is in line with several studies that reported same disorders (49). The failure of the primary antioxidant system to act against free radicals generated may reflect the inability of liver mitochondria and microsomes to eliminate hydrogen peroxide produced after exposure to bisphenol A. This may also be due to enzyme inactivation caused by excess ROS production in mitochondria and microsomes (31). These findings are linked to histopathological changes in treated animals. Where, liver tissue of BPA treated rats shows congestions of hepatoportal blood vessels (blue arrow), inflammatory infiltrations (black arrow) and degeneration of hepato- cytes (asterisk) with necrotic foci scattered throughout the liver $(\mathrm{N})$. Although, experimental studies have shown that BPA is rapidly metabolized and excreted in rodents (50). It was reported an accumulation of bisphenol A in several target organs (brain, gonads and liver) following three oral doses $(0.1,10$ or $100 \mathrm{mg} / \mathrm{kg})$ of ${ }^{14} \mathrm{C}$-bisphenol A in Fischer 344 female rats (51). In addition, previous studies confirm that human environmental exposure to BPA is continuously as an inhaled or swallowed dust or by ingestion of migrated polymer from polycarbonates $(52,53)$.

Dietary Selenium and vitamin E attenuated the above findings. Antagonism between (Se and Vit E) and BPA was noticed where a decline of lipid peroxidation and a recovery of antioxidant enzymatic activities of GPx, GST and CAT were recorded in the fourth group. This amelioration is reflected by a reduced inflammatory infiltration in the hepatic tissue. In a previous study, it was reported that selenium effectively reinforces cellular antioxidant 
activity against atrazine-induced changes in rats by increasing hepatic glutathione, glutathione peroxidase, superoxide dismutase activity, and ascorbate content while hepatic catalase activities decreased (47-49). In addition, previous studies demonstrated crucial effects of selenium and vitamin $\mathrm{E}$ in synergy $(16,25,29,50-55)$, selenium alone $(17,18)$ and vitamin $\mathrm{E}$ alone $(19,20,56)$. Therefore, an earlier study reported that selenium-deficiency and vitamin E-deficiency are susceptible to induce body functional abnormalities such as haemolysis of erythrocytes $(57,58)$. Collectively, co-treatment of selenium and vitamin E revealed a significant reduction in lipid peroxidation content and an improvement in GSH level. In addition, a reinforcement of enzymatic activities of the liver was found. Nonetheless, more studies are needed to evaluate their repairing capacities on histopathological changes.

\section{ACKNOWLEDGMENTS}

The present research was supported by the Algerian Ministry of Higher Education and Scientific Research, Directorate General for Scientific Research and Technological Development through the Research Laboratory "Laboratory of Biochemical and Environmental Toxicology" Faculty of Sciences, Badji Mokhtar University, Annaba, Algeria.

Received November 10, 2017; Revised April 26, 2018; Accepted April 30, 2018

\section{REFERENCES}

1. INRS (2016) Fiche Toxicologique $N^{0} 279$ Edition 03/11/ 2013 Et Le 01/01/2016. Available from: http://www.Inrs.Fr/ Fichetox/.

2, Takeshita, A., Koibuchi, N., Oka, J., Taguchi, M., Shishiba, Y. and Ozawa, Y. (2001) Bisphenol-A, an environmental estrogen, activates the human orphan nuclear receptor, steroid and xenobiotic receptor-mediated transcription. Eur. J. Endocrinol., 145, 513-517.

3. Kang, J.H., Kondo, F. and Katayama, Y. (2006) Human exposure to bisphenol A. Toxicology, 226, 79-89.

4. Anjum, S., Rahman, S., Kaur, M. and Ahmad, F. (2011) Melatonin ameliorates bisphenol a-induced biochemical toxicity in testicular mitochondria of mouse. Food Chem. Toxicol., 49, 2849-2854.

5. Ko, A., Hwang, M.S., Park, J.H., Kang, H.S., Lee, H.S. and Hong, J.H. (2014) Association between urinary bisphenol A and waist circumference in Korean adults. Toxicol. Res., 30, $39-44$.

6. Routledge, E.J., White, R., Parker, M.G. and Sumpter, J.P. (2000) Differential effects of xenoestrogens on coactivator recruitment by estrogen receptor (ER) alpha and ER beta. $J$. Biol. Chem., 275, 35986-35993.

7. Bouskine, A., Nebout, M., Brucker-Davis, F., Benahmed, M. and Fenichel, P. (2009) Low doses of bisphenol A promote human seminoma cell proliferation by activating PKA and PKG via a membrane G-protein-coupled estrogen receptor. Environ. Health Perspect., 117, 1053-1058.

8. Sargis, R.M., Johnson, D.N., Choudhury, R.A. and Brady, M.J. (2010) Environmental endocrine disruptors promote adipogenesis in the 3T3-L1 cell line through glucocorticoid receptor activation. Obesity, 18, 1283-1288.

9. Takayanagi, S., Tokunaga, T., Liu, X.H., Okada, H., Matsushima, A. and Shimohigashi, Y. (2006) Endocrine disruptor bisphenol A strongly binds to human estrogen-related receptor gamma (ERR gamma) with high constitutive activity. Toxicol. Lett., 167, 95-105.

10. D'Cruz, S.C., Jubendradass, R., Jayakanthan, M., Rani, S.J. and Mathur, P.P. (2012) Bisphenol A impairs insulin signaling and glucose homeostasis and decreases steroidogenesis in rat testis. Food Chem. Toxicol., 50, 1124-1133.

11. Vandenberg, L.N., Maffini, M.V., Sonnenschein, C., Rubin, B.S. and Soto, A.M. (2009) Bisphenol-A and the great divide: a review of controversies in the field of endocrine disruption. Endocr. Rev., 30, 75-95.

12. Melzer, D., Rice, N.E., Lewis, C., Henley, W.E. and Galloway, T.S. (2010) Association of urinary bisphenol a concentration with heart disease: evidence from NHANES 2003/06. PLOS ONE, 5, e8673.

13. Krieter, D.H., Canaud, B., Lemke, H.D., Rodriguez, A., Morgenroth, A., von Appen, K., Dragoun, G.P. and Wanner, C. (2013) Bisphenol A in chronic kidney disease. Artif. Organs, 37, 283-290.

14. Ronn, M., Kullberg, J., Karlsson, H., Berglund, J., Malmberg, F., Orberg, J., Lind, L., Ahlström, H. and Lind, P.M. (2013) Bisphenol A exposure increases liver fat in juvenile fructose-fed Fischer 344 rats. Toxicology, 303, 125-132.

15. Schieber, M. and Chande, N.S. (2014) ROS function in redox signaling and oxidative stress review. Curr. Biol., 24, R453-R462.

16. Cemek, M., Büyükokuroğlu, M.E., Büyükben, A., Aymelek, F. and Özcan, L. (2010) Effects of vitamin E and selenium on tissue bio-element status in organophosphate toxicity of rats. Pestic. Biochem. Physiol., 98, 9-18.

17. Ognjanovic, B.I., Markovic, S.D., Pavlovic, S.Z. and Zikic, R.V. (2008) Effect of chronic cadmium exposure on antioxidant defense system in some tissues of rats: protective effect of selenium. Physiol. Res., 57, 403-411.

18. Ben Amara, I., Fetoui, H., Guermazi, F. and Zeghal, N. (2009) Dietary selenium addition improves cerebrum and cerebellum impairments induced by methimazole in suckling rats. Int. J. Dev. Neurosci., 27, 719-726.

19. Bansal, A.K., Bansal, M., Soni, G. and Bhatnagar, D. (2005) Protective role of Vitamin E pre-treatment on N-nitrosodiethylamine induced oxidative stress in rat liver. Chem. Biol. Interact., 156, 101-111.

20. Al-Attar, A.M. (2011) Antioxidant effect of vitamin E treatment on some heavy metals-induced renal and testicular injuries in male mice. Saudi. J. Biol. Sci., 18, 63-72.

21. Messarah, M., Amamra, W., Boumendjel, A., Barkat, L., Bouasla, I., Abdennour, C., Boulakoud, M.S. and El Feki, A. (2013) Ameliorating effects of curcumin and vitamin E on diazinon-induced oxidative damage in rat liver and erythrocytes. Toxicol. Ind. Health, 29, 77-88. 
22. Bowry, V.W., Ingold, K.U. and Stocker, R. (1992) Vitamin E in human low-density lipoprotein. When and how this antioxidant becomes a pro-oxidant. Biochem. J., 288, 341-344.

23. Scott, L.D., Kelleher, J. and Losowsky, M.S. (1977) The influence of dietary selenium and vitamin e on glutathione peroxidase and glutathione in the rat. Biochim. Biophys. Acta, 497, 218-224.

24. Abdel Samie, H.A., Nassar, S.A. and Hussein, Y. (2013) Ameliorative potential of selenium against bisphenol Ainduced hepatotoxicity in rats. Egypt. J. Hosp. Med., 67, 444-454.

25. Chow, C.K. (1990) Effect of dietary vitamin E and selenium on rats: pyruvate kinase, glutathione peroxidase and oxidative damage. Nutr. Res., 10, 183-194.

26. Fang, Y., Zhou, Y., Zhong, Y., Gao, X. and Tan, T. (2013) Effect of vitamin $\mathrm{E}$ on reproductive functions and anti-oxidant activity of adolescent male mice exposed to bisphenol A. Wei Sheng Yan Jiu, 42, 18-22.

27. Abedelhaffez, A.S., Abd El-Aziz, E.A., Abdel Aziz, M. and Ahmed, A.M. (2017) Lung injury induced by bisphenol A: a food contaminant is ameliorated by selenium supplementation. Pathophysiology, 24, 81-89.

28. Nazıroglu, M., Karaoglu, A. and Aksoy, A.O. (2004) Selenium and high dose vitamin $\mathrm{E}$ administration protects cisplatin-induced oxidative damage to renal, liver and lens tissues in rats. Toxicology, 195, 221-230.

29. Ben Amara, I., Soudani, N., Troudi, A., Bouaziz, H., Boudawara, T. and Zeghal, N. (2011) Antioxidant effect of vitamin $\mathrm{E}$ and selenium on hepatotoxicity induced by dimethoate in female adult rats. Ecotoxicol. Environ. Saf., 74, 811819.

30. Mulaikal, J. and Emond, C. (2012) Physiology and Anatomy of the Liver (Gebhard, W. Eds.). Gebhard Wagener Editor, MD, pp. 3-20.

31. Nakagawa, Y. and Tayama, S. (2000) Metabolism and cytotoxicity of bisphenol A and other bisphenols in isolated rat hepatocytes. Arch. Toxicol., 74, 99-105.

32. El-Beshbishy, H.A., Aly, H.A. and El-Shafey, M. (2012) Lipoic acid mitigates bisphenol a-induced testicular mitochondrial toxicity in rats. Toxicol. Ind. Health, 29, 875.

33. European Commission (2007) Commission Recommendations of 18 June 2007 on Guidelines for the Accommodation and Care of Animals Used for Experimental and Other Scientific Purposes. Annex II to European Council Directive 86/609. 2007/526/EC.

34. Buege, J.A. and Aust, S.D. (1984) Microsomal lipid peroxidation. Methods Enzymol., 105, 302-310.

35. Ellman, G.L. (1959) Tissue sulfhydryl groups. Arch Biochem. Biophys., 82, 70-77.

36. Habig, W.H., Pabst, M.J. and Jakoby, W.B. (1974) Glutathione-S-transferase the first step in mercapturic acid formation. J. Biol. Chem., 249, 7130-7139.

37. Flohe, L. and Gunzler, W.A. (1984) Analysis of glutathione peroxidase. Methods Enzymol., 105, 114-121.

38. Aebi, H. (1984) Catalase in vitro. Methods Enzymol., 105, 121-126.

39. Bradford, M. (1976) A rapid and sensitive method for the quantities of microgram quantities of protein utilizing the principle of protein-dye binding. Anal. Biochem., 72, 248-
254.

40. Vom Saal, F.S., Nagel, S.C., Coe, B.L., Angle, B.M. and Taylor, J.A. (2012) The estrogenic endocrine disrupting chemical bisphenol A (BPA) and obesity. Mol. Cell. Endocrinol., 354, 74-84.

41. Huc, L., Lemarié, A., Guéraud, F. and Héliès-Toussaint, C. (2012) Low concentrations of bisphenol A induce lipid accumulation mediated by the production of reactive oxygen species in the mitochondria of HepG2 cells. Toxicol. In Vitro, 26, 709-717.

42. Honma, S., Suzuki, A., Buchanan, D.L., Katsu, Y., Watanabe, H. and Iguchi, T. (2002) Low dose effect of in utero exposure to bisphenol A and diethylstilbestrol on female mouse reproduction. Reprod Toxicol., 16, 117-122.

43. Ryan, B.C. and Vandenbergh, J.G. (2006) Developmental exposure to environmental estrogens alters anxiety and spatial memory in female mice. Horm. Behav., 50, 85-93.

44. Korkmaz, A., Ahbab, M.A., Kolankaya, D. and Barlas, N. (2010) Influence of vitamin C on bisphenol A, nonylphenol and octylphenol induced oxidative damages in liver of male rats. Food Chem. Toxicol., 48, 2865-2871.

45. Hassan, Z.K., Elobeid, M.A., Virk, P., Omer, S.A., ElAmin, M., Daghestani, M.H. and AlOlayan, E.M. (2012) Bisphenol A induces hepatotoxicity through oxidative stress in rat model. Oxid. Med. Cell. Longev., 2012, 194829.

46. Helal, E.G.E., Taha, N.M., Ahmed, M.M. and Abu-Taleb, H.M. (2016) Ameliorative effect of vitamin E on oxidative stress induced by bisphenol A in female albino rats. Egypt. J. Hosp. Med., 65, 474-478.

47. Favier, A. (2003) Oxidative stress: conceptual and experimental interest in comprehension mechanism of diseases and therapeutic potentiel. Biochimical mechanism. L'actualité Chimique, 5, 108-115.

48. Sorg, O. (2004) Oxidative stress: a theoretical model or a biological reality. C. R. Biol., 327, 649-662.

49. Yildız, N. and Barlas, N. (2013) Hepatic and renal functions in growing male rats after bisphenol $\mathrm{A}$ and octylphenol exposure. Hum. Exp. Toxicol., 32, 675-686.

50. Kurebayashi, H., Betsui, H. and Ohno, Y. (2003) Disposition of a low dose of 14C-bisphenol $\mathrm{A}$ in male rats and its main biliary excretion as BPA glucuronide. Toxicol. Sci., 73, 17-25.

51. Kim, C.S., Sapienza, P.P., Ross, I.A., Johnson, W., Luu, H.M. and Hutter, J.C. (2004) Distribution of bisphenol A in the neuroendocrine organs of female rats. Toxicol. Ind. Health, 20, 41-50.

52. Staples, C.A., Dorn, P.B., Klecka, G.M., O'Block, S.T. and Harris, L.R. (1998) A review of the environmental fate, effects, and exposures of bisphenol A. Chemosphere, 36, 2149-2173.

53. Adebukola, C., Adesiyan, A., Titilola, O., Oyejola, M.O. and Farombi, E.O. (2011) Selenium provides protection to the liver but not the reproductive organs in an atrazine-model of experimental toxicity. Exp. Toxicol. Pathol., 63, 201-207.

54. El-Demerdash, F.M. (2004) Antioxidant effect of vitamin E and selenium on lipid peroxidation, enzyme activities and biochemical parameters in rats exposed to aluminium. $J$. Trace Elem. Med. Biol., 18, 113-121.

55. Gueroui, M. and Kechrid, Z. (2016) Evaluation of some bio- 
chemical parameters and brain oxidative stress in experimental rats exposed chronically to silver nitrate and the protective role of vitamin e and selenium. Toxicol. Res., 32 , 301-309.

56. Lee, J. (2010) Use of antioxidants to prevent cyclosporine a toxicity. Toxicol. Res., 26, 163-170.

57. Messarah, M., Klibet, F., Boumendjel, A., Abdennour, C., Bouzerna, N., Boulakoud, M.S. and El Feki, A. (2012)
Hepatoprotective role and antioxidant capacity of selenium on arsenic-induced liver injury in rats. Exp. Toxicol. Pathol., 64, 167-174.

58. Djeffal, A., Messarah, M., Boumendjel, A., Kadeche, L. and El Feki, A. (2015) Protective effects of vitamin C and selenium supplementation on methomyl-induced tissue oxidative stress in adult rats. Toxicol. Ind. Health, 31, 31-43. 